\title{
Variability of amphidromous organism isotopic niches in three Guadeloupe rivers affected by damming and water catchment
}

\section{Lou Frotté ${ }^{1}$, Loïc Michel ${ }^{2}$, Gilles Lepoint ${ }^{3}$, Sébastien Cordonnier ${ }^{1}$, Étienne Bezault ${ }^{1}$ \& Dominique Monti ${ }^{1,4^{*}}$}

${ }^{1}$ UMR BOREA, UA-MNHN-SU-IRD-CNRS-UCN, Université des Antilles, BP 592, 97157 Pointe-à-Pitre, Guadeloupe, France.

${ }^{2}$ Ifremer, Centre de Bretagne, REM/EEP, Laboratoire Environnement profond, Plouzané, France.

${ }^{3}$ Laboratory of Oceanology, MARE Centre, UR FOCUS, University of Liège,

15 allée du six août, B-4000 Liège, Belgium.

${ }^{4}$ Institut de Systématique, Évolution, Biodiversité (ISYEB), Université des Antilles, MNHN, CNRS, SU, EPHE, BP 592, 97157 Pointe-à-Pitre, Guadeloupe, France.

\section{*Corresponding author: dominique.monti@univ-antilles.fr}

\begin{abstract}
Native fauna of the tropical volcanic part of Guadeloupe is amphidromous: juveniles born in rivers but that grow in the sea need to migrate upstream to colonise their adult habitat in rivers. This migration is affected by any human-made obstacles placed in their way. Moreover, on volcanic tropical islands, streams are the main source of water catchment for the human population. This deeply affects river hydrology and characteristics. Both damming and water catchment potentially affect community diversity and species demography, but they may also alter the trophic ecology of the river fauna. Using stable isotopes and the stable isotope Bayesian ellipses approach in R (SIBER), this study aimed to assess the isotopic niche variability of riverine fauna of three persistent small rivers of Basse-Terre Island (Guadeloupe) affected by damming and water catchment. Using electrofishing, decapods and fishes (gobies) of three rivers were sampled upstream and downstream of dams. Our results demonstrated that the variability of the isotopic niches was extremely high between rivers but varied less between stations of the same river. Our results revealed complex and river-specific effects and a pattern merged with natural variability. Our two hypotheses (i.e., increase of resources upstream of dams and differential responses of trophic guilds to damming and water catchment) were only weakly supported and never in an unambiguous manner. Our study showed that it is necessary to consider the 'noise' generated by natural variability to observe and understand changes in the trophic ecology of associated fauna in relation to damming and water catchment.
\end{abstract}

Keywords. Amphidromous species, stable isotopes, tropical stream, West Indies.

Frotté L., Michel L., Lepoint G., Cordonnier S., BeZAult É. \& Monti D. (2021). Variability of amphidromous organism isotopic niches in three Guadeloupe rivers affected by damming and water catchment. Belgian Journal of Zoology 151: 63-80. https://doi.org/10.26496/bjz.2021.86 


\section{Introduction}

The volcanic part of the Guadeloupe (Basse-Terre) presents many persistent rivers that support original native communities, dominated by freshwater crustaceans (Atyidae and Palaemonidae shrimps and crabs), molluscs and fish (mainly Gobiidae). Most of them are amphidromous (KEITH 2003; TABOURET et al. 2011; WATANABE et al. 2013; SMITH \& KWAK 2014; ENGMAN et al. 2018): the adults live and breed in freshwater, but their larvae migrate to the sea after hatching and grow into adulthood in coastal areas (MYERS 1949; MCDOWALL 1997). After several weeks in saline waters, the post larvae re-enter the freshwater ecosystems through the river mouths and migrate upstream to their adult habitats (MYERS 1949; MCDOWALL 1997).

During their juvenile migration to the upstream habitats, amphidromous fauna must cross all obstacles located in the riverbeds. They encounter many dams built by humans for diverse purposes (water reservoir and water catchment for irrigation or drinking water, hydroelectricity, etc.). In the context of an increase in the human population and freshwater resource limitation due to marked dry seasons, the rivers of tropical islands are essential because they ensure the production of tap water as well as the supply of freshwater for agriculture (MARCH et al. 2003). Nevertheless, the concrete structures built for water supply represent significant physical obstacles that could strongly affect ecological continuity and hamper the migratory behaviour of fish or crustacean juveniles (MARCH et al. 2003; GREATHOUSE et al. 2006; JENKINS et al. 2010; COONEY \& KWAK 2013; FROTTÉ et al., 2020b). The adults could also perform movements between refugia, feeding and spawning habitats throughout their lives. In many rivers, these movements are perturbed by obstacles, with small obstacles not being as insignificant as initially thought, because they have been shown as significantly disrupting and/or obstructing their movements (OVIDIO \& PHILIPPART 2002). These structures can produce a bottleneck effect in stopping juveniles and slowing down the adults in their upstream movement, increasing the densities of upstream migrating animals below the dam (i.e., crowding effect) (BENSTEAD et al. 1999).

Small low-head dams do not act as a complete barrier to upstream migrations but rather more as a filter. These structures are often called 'biologically porous', operating selectively on species and individual sizes. Crossing these physical obstacles is strongly influenced by the morphological traits of each species, which determines their ability to move upstream and to reach the upper part of the river (KEITH 2003; KiKKERT et al. 2009, MONTI et al. 2018). For example, Atya spp. have the highest upstream movement or migration capacity, with their robust walking legs equipped with claws and a body profiled with a hydrodynamic shape, allowing them to move in highly dynamic flows (KIKKERT et al. 2009). The Gobiidae, Sicydium spp., have modified fused pelvic fins that form a pelvic sucker, enabling them to hold on to rocks in dynamic flows and to climb waterfalls or dams (KEITH 2003).

A special characteristic of damming in Guadeloupe is its usage for drinking water production and therefore the catchment of a substantial quantity of water from the river. Currently, 117 flow-altering structures are listed in Guadeloupe (SANDRE \& EAU FRANCE 2019), and 73 of them are directly linked to water withdrawal, which represents an annual volume of 80-90 million $\mathrm{m}^{3}$. Tap water production is achieved by direct river water catchment. Extracting a fraction of the above-ground water implies a decrease in downstream water resources. This can lead to a decrease in habitat surfaces and availability for aquatic organisms, potentially affecting their abundance and diversity (PRINGLE 1997; FREEMAN et al. 2003; SMITH et al. 2003; COONEY \& KWAK 2013). In addition, the reduction in natural flows could differentially affect the species living in Caribbean freshwater rivers, as they have different hydrological regime preferences (e.g., FIĖVET et al. 2001a, 2001b). The water flow reduction by water catchments also alters downstream communities through local crowding effects resulting from habitat contraction. This effect cumulates with that of obstacles on upstream juvenile migration or adult movement (COVICH et al. 2003). 
FROTTÉ L. et al., Trophic niches of Caribbean freshwater fauna in dammed rivers

The disruption of the ecological continuum and the water flow by damming and water catchment can affect not only the population demography or the community composition but also the energy flow, species trophic interactions and the trophic functioning of the ecosystem. For example, the crowding effect can result in differential predation risk (i.e., attraction of opportunistic predators) and an increase in trophic competition if trophic resources are limited (COVICH et al. 2003; MARCH et al. 2003).

In mid to high elevations (i.e., the main location of the freshwater catchments in rivers), the animal community is less diverse than in low elevations because of the relative scarcity of fish (i.e., 5-15 species vs 30 species) (MONTI et al. 2010). Despite this low specific diversity, the trophic diversity found in these rivers is relatively high, with species relying on both autochthonous and/or allochthonous food sources (COAT et al. 2009). Some of these species have been shown to possess the ability to adapt their diet (or their feeding mode) to local conditions (i.e., water regime, food source abundance, etc.) (COAT et al. 2009; LEFRANÇOIS et al. 2011). For example, the Atyidae are suspension feeders adapted to fast water flows with two pairs of legs modified to collect drifting particulate matter, but they can also be epilithic biofilm brushers when the current is weaker (PRINGLE \& BLAKE 1994; COVICH et al. 1999; FREEMAN et al. 2003). The freshwater Palaemonidae species in Guadeloupe mostly belong to the genus Macrobrachium, which are territorial detritus feeders and opportunistic predators (COVICH et al. 1999; DUDGEON 1999). These Macrobrachium species do not share exactly the same sub-habitat and, when encountered together, do not display exactly the same diet: the larger species act generally more as opportunistic carnivores than smaller ones (DUDGEON 1999; XU et al. 2008; COAT et al. 2009). They are also able to adapt to local environmental conditions and community composition.

The autochthonous production of organic matter in the Guadeloupe stream is low compared to temperate rivers and is represented quite exclusively by a very adherent epilithic biofilm growing on stones (LEFRANÇOIS et al. 2011; MONTI et al. 2018). Despite this relatively low production, autochthonous resources are possibly more important than allochthonous food for secondary production in many tropical headwater streams (LAU et al. 2009). In Guadeloupe's small streams, Coat et al. (2009) have shown that allochthonous matter contributes significantly to many animal diets, particularly in the mid-to highelevation portion of rivers. Phytoplankton biomass is absent from these rivers, and drifting matter is composed of diverse detritus particles originating from riparian flora (i.e., dead tree leaves, fruits, etc.). The creation of a lentic habitat by damming could change the basic characteristics of autochthonous primary production (i.e., creation of calmer and deeper water zones), and decreased water flows can diminish primary production downstream (i.e., loss of habitat) or change its characteristic (i.e., change in the hydrological regime). Indeed, biofilm production and characteristics are also known to be impacted by local hydrodynamics (BIGGS \& CLOSE 1989).

On the other hand, allochthonous matter is likely to be retained upstream of the water catchment, decreasing the diversity and abundance of downstream food sources. Resource limitations, as well as the crowding effect of damming and the water flow reduction, raise the question of potential competition for resources between species sharing similar trophic niches. Therefore, obstacles to the water flow could have an effect on the local fauna's trophic ecology and on the relative contribution of autochthonous versus allochthonous material to the animal diets (KUPILAS et al. 2016).

Stable isotopic analyses are extensively applied in aquatic ecosystems as powerful methods to assess the trophic ecology of animals thanks to their ability to record time-integrated and assimilated diets (LAYMAN et al. 2007, 2012). Using stable isotope niches as a proxy, this approach is useful to characterise the trophic niches of species or assemblages (LAYMAN et al. 2012). The use of carbon and nitrogen isotopic composition of individuals is very pertinent in Caribbean rivers because they allow identification of the relative importance of autochthonous vs allochthonous contributions of matter in animal diet and potential isotopic niche changes (COVICH et al. 1999; LAU et al. 2009; COAT et al. 2009). 
In our study, we assessed the isotopic niche variability of riverine fauna of three persistent rivers of Basse-Terre Island affected by damming and water catchment. We sampled communities upstream and downstream of dams and extraction systems and compared isotopic niches at both community and trophic-guild levels. First, we hypothesised that the higher water availability upstream from the water catchments would lead to greater diversity of habitat and food sources, resulting in wider trophic niches for species and assemblages. Second, we hypothesised that herbivores and omnivores would be more affected than suspension feeders. The latter indeed feed on two basal food sources, namely drifting particulate matter and biofilm, with the biofilm being strictly dependent on where it grows and the drifting particulate matter having homogeneous carbon and nitrogen isotopic composition on either side of the water catchment.

\section{Material and methods}

\section{Study sites}

The study took place in three persistent rivers located in the volcanic part of Guadeloupe Island: Grand Carbet River, Pérou River and Moreau River (Fig. 1). These rivers were located on the windward side of the hydrographic region, with similar elevation, slope and hydrographic regimes (Table 1). These were typical volcanic tropical rivers with shallow waters and highly hydrodynamic characteristics, a reduced mouth and a rapidly increasing slope (Table 1). All contain more than one major concrete structure built for water catchment in their riverbed. The selected sites present similar environmental characteristics, except that the Moreau site is devoted to high banks with tropical forests. By contrast, the three sites differed by the characteristics of damming and water catchment effect (Fig. 1, Table 1). Moreau featured an unusual, very low construction $(0.1 \mathrm{~m}$ high at low water level) located on an open sky riverbed, with large planar concrete consolidations downstream. The upstream water retention created was the shallowest and the narrowest of the three rivers. Pérou's water catchment had medium height ( $4 \mathrm{~m}$ at low water level), whereas Grand Carbet's was the highest concrete construction (5 $\mathrm{m}$ at low water level). Dams were not specifically equipped with complex fish pathways, but in Grand Carbet and Pérou Rivers, a water extraction canal partly allowed the fauna to bypass the dam. Damming generated an upstream water retention wider at

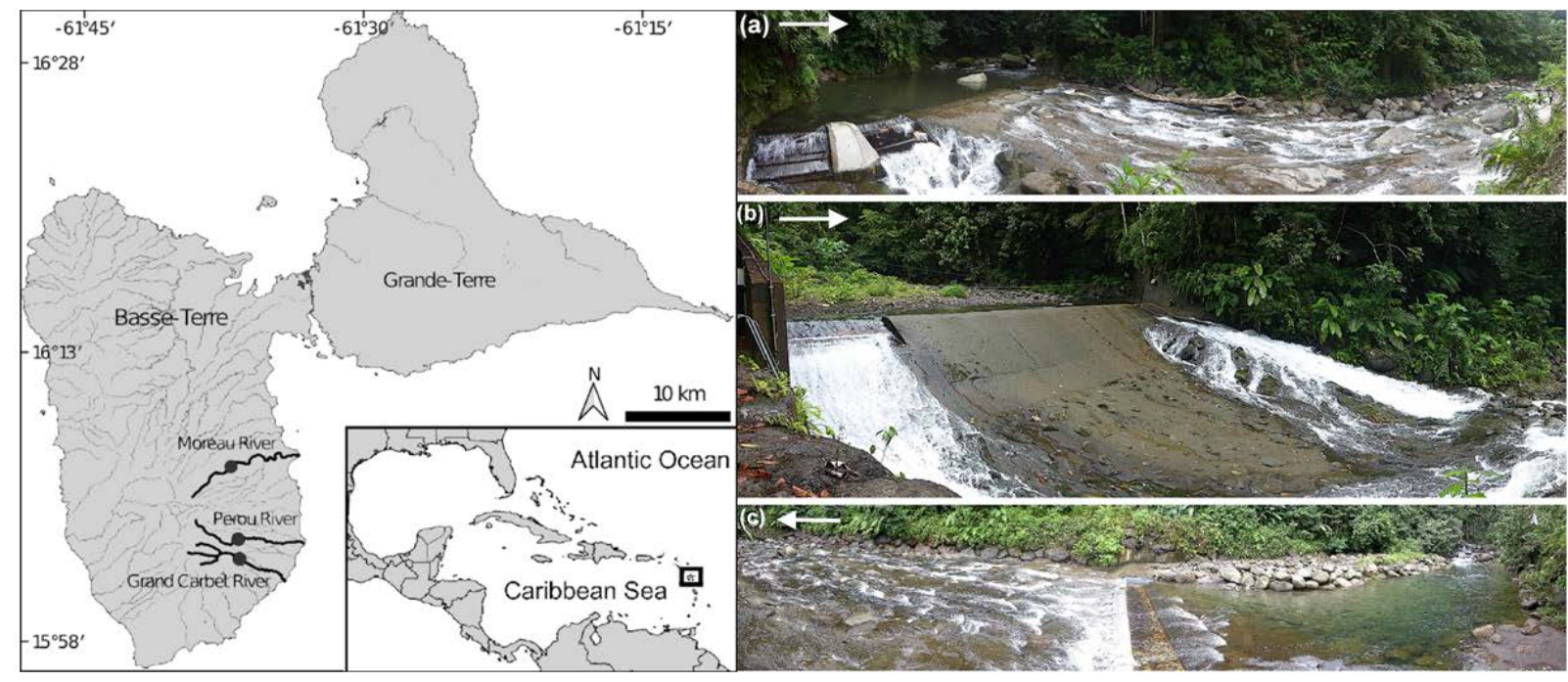

Fig. 1 - Left: map of Guadeloupe with the sampled rivers (bold lines) and sampling locations (dots). Right: pictures of sampling sites (i.e., water catchments associated with damming) on the rivers Grand Carbet (a), Pérou (b) and Moreau (c). Direction of the arrow indicates the direction of the current. For each river, sampling of an anadromous community was done upstream and downstream of the dam. 
TABLE 1

Location and general characteristics of the three tropical rivers (Guadeloupe), their damming and of associated water catchment.

\begin{tabular}{|c|c|c|c|}
\hline & Moreau & Pérou & Grand Carbet \\
\hline Station location $\left(\right.$ long $^{\circ} ;$ lat $^{\circ}$ ) & $\begin{array}{l}-61.62163333^{\circ} \\
16.12001667^{\circ}\end{array}$ & $\begin{array}{l}-61.61527778^{\circ} \\
16.05738889^{\circ}\end{array}$ & $\begin{array}{l}-61.61168333^{\circ} \\
16.03878333^{\circ}\end{array}$ \\
\hline \multicolumn{4}{|l|}{$\begin{array}{l}\text { River and sampling sites } \\
\text { characteristics }\end{array}$} \\
\hline River type & persistent river & persistent river & persistent river \\
\hline Altitude (m) & 174 & 251 & 212 \\
\hline River bottom & $\begin{array}{c}\text { andesite rocks with } \\
\text { an average diameter greater } \\
\text { than the thickness of } \\
\text { the water layer }\end{array}$ & $\begin{array}{c}\text { andesite rocks with } \\
\text { an average diameter greater } \\
\text { than the thickness of } \\
\text { the water layer }\end{array}$ & $\begin{array}{c}\text { andesite rocks with } \\
\text { an average diameter greater } \\
\text { than the thickness of } \\
\text { the water layer }\end{array}$ \\
\hline Average rate of flow $\left(\mathrm{m}^{3} \cdot \mathrm{s}^{-1}\right)^{*}$ & 6.3 & 13.5 & 15.1 \\
\hline Distance to river mouth $(\mathrm{km})$ & 9.3 & 7.8 & 6.8 \\
\hline $\begin{array}{l}\text { Watershed upstream of } \\
\text { the measurements }\left(\mathrm{km}^{2}\right)\end{array}$ & 7.4 & 9.2 & 9.3 \\
\hline $\begin{array}{l}\text { Area and depth of upstream } \\
\text { reservoir at sampling date }\end{array}$ & $\begin{array}{l}240 \mathrm{~m}^{2} \text { with a mean depth of } \\
\qquad 40 \mathrm{~cm}\end{array}$ & $\begin{array}{l}46 \mathrm{~m}^{2} \text { and a mean depth } \\
\text { of } 30 \mathrm{~cm}\end{array}$ & $\begin{array}{c}300 \mathrm{~m}^{2} \text { with a mean depth } \\
\text { of } 70 \mathrm{~cm}\end{array}$ \\
\hline $\begin{array}{l}\text { Depth and width of upstream } \\
\text { water intake sampling site at } \\
\text { sampling date }(\mathrm{m}, \mathrm{m})\end{array}$ & $0.3,7-9$ & $0.3,4-6$ & $0.3,7-9$ \\
\hline $\begin{array}{l}\text { Depth and width } \\
\text { of downstream sampling site } \\
\text { at sampling date }(\mathrm{m}, \mathrm{m})\end{array}$ & $0.22,10-12$ & $0.27,12-15$ & $0.34,4-6$ \\
\hline Bank characteristics & $\begin{array}{c}\text { grassy banks devoted } \\
\text { of trees }\end{array}$ & banks with tropical forest & banks with tropical forest \\
\hline \multicolumn{4}{|l|}{ Damming characteristics } \\
\hline Description & $\begin{array}{l}\text { low dam with large planar } \\
\text { concrete ramp, downstream }\end{array}$ & $\begin{array}{l}\text { high dam with a medium } \\
\text { concrete ramp, downstream }\end{array}$ & $\begin{array}{c}\text { a pair a two small twin dams } \\
\text { with large concrete ramp, } \\
\text { downstream }\end{array}$ \\
\hline Height at low water (m) & 0.1 & 4 & 5 \\
\hline Fauna bypass & yes & yes & yes \\
\hline Bypass description & concrete simple indentation & $\begin{array}{l}\text { andesitic rocks of various } \\
\text { size consolidated } \\
\text { by concrete (natural aspect } \\
\text { mimetic of a large } \\
\text { sediment overflow) }\end{array}$ & $\begin{array}{l}\text { long concrete artificial } \\
\text { channel }\end{array}$ \\
\hline
\end{tabular}

*data provided by DEAL Guadeloupe 
Grand Carbet and Moreau rivers and deeper at Grand Carbet (Table 1). For each river, two stations were selected: one directly downstream of the water catchment and one located directly upstream of the construction. The organisms were sampled over the entire width of the rivers from the dam and over a length ranging between 50 and $95 \mathrm{~m}$ to cover a comparable area between rivers.

\section{Sample collection}

Specimens of fish and crustaceans were collected through electrofishing (Deka 3000 electrofisher, DekaGerätebau, Germany) from February to May 2017 (Table 2). Electro-anaesthesia was implemented with direct current (DC) because alternating current has long been known to be the most damaging wave form to fish (LAMARQUE 1990; WALKER et al. 1994). The device was equipped with a 12 V DC shocking circular anode covered with a net and powered by a motorcycle battery. The shock was set at the minimum output voltage and a time of 15 to $30 \mathrm{~s}$. The collected animals were identified and counted within a minute and released immediately in the river directly downstream of the sampling point with no withdrawal time. Eight species with the most abundant two ontogenetic stages (adults and juveniles) were caught in the three rivers (Table 2). Fish were represented by Gobiidae Sicydium plumieri (Bloch, 1786) and Sicydium punctatum Perugia, 1896. Crustaceans were represented by three families: Atyidae with Atya innocous Herbst, 1792, Micratya poeyi (Guérin-Méneville, 1855) and Potimirim potimirim (Mueller, 1881); Palaemonidae with Macrobrachium faustinum (de Saussure, 1857) and Macrobrachium heterochirus (Wiegmann, 1836); and Xiphocarididae with Xiphocaris elongata (Guérin-Méneville, 1855). Abundance and diversity data were published in FrOTTÉ et al. (2020a). Six individuals per species (or age classes when juveniles and adults were simultaneously present) were set aside for isotopic analyses and sacrificed by immediate freezing in liquid nitrogen to maintain their chemical characteristics. Stable isotope composition of animals can be related to size (i.e., ontogenetic trophic shifts and/or increase of trophic position according to prey size increase). In addition, the fact these animals are amphidromous with the colonisation of the river by juveniles may imply growing individuals are not completely in the isotopic equilibrium with their riverine diet (i.e., keep a part of their marine diet and therefore marine isotopic signal) (COAT et al. 2009). Therefore, adults and juveniles were separated, and adult individuals of similar size were selected from the collected samples (Table 2). Sampled food sources included items previously determined as contributing to fish and crustacean diet in the rivers of Guadeloupe (COAT et al. 2009), that is, epilithic biofilm $(\mathrm{n}=6$ samples per sampling site), fresh and decomposed leaf litter ( $\mathrm{n}=6$ samples per sampling site) and drifting particulate organic matter (POM, $\mathrm{n}=2$ samples per sampling site). The epilithic biofilm was scraped from stones from rapid and slow habitats, fresh and decomposed leaf litter was picked by hand in the river, and the drifting POM was caught with a plankton net ( $64 \mu \mathrm{m}$ mesh size) placed in the mainstream of the river flow for $2 \mathrm{~h}$. The biofilm and the drifting POM were filtered through GF/F Whatman glass fibre filter ( $0.7 \mu \mathrm{m}$ porosity). All samples were frozen at $-80^{\circ} \mathrm{C}$ pending species identification and preparation for isotopic analyses.

\section{Preparation and isotopic analyses}

Pieces of muscle tissue without bones, skin or scales (for fishes) or cuticles (for shrimp) were dissected from later dorsal (for fishes) or abdominal muscle (for shrimp). For the smallest shrimp specimens, abdomens were analysed in whole after cuticle removal. All animal and vegetal samples were oven dried at $50^{\circ} \mathrm{C}$ for at least $48 \mathrm{~h}$, then grounded into a homogeneous fine powder with either mortar and pestle or, in the case of leaf samples, a mixer mill (MM 301, Retsch GmBH, Haan, Germany). Carbon and nitrogen stable isotope ratios were measured with an isotope ratio mass spectrometer (IsoPrime100, Isoprime, UK) coupled in a continuous flow to an elemental analyser (Vario Micro cube, Elementar, Germany) for combustion and automated analysis. According to Coplen (2011), stable isotope ratios were expressed in $\delta$ notation in \%o and relative to the international references Vienna Pee Dee Belemnite (for carbon) and atmospheric air (for nitrogen). International Atomic Energy Agency (IAEA, Vienna, Austria) certified 


\section{TABLE 2}

Numbers of individuals sampled and analysed (number in brackets) by species and ontogenetic stages for the three water catchments. Sicydinnae: Sicydium plumieri (Spl), S. punctatum (Spu) and Sicydium spp. juveniles (SppJ); Atyidae: Atya innocous adults (Ain) and juveniles (AinJ), Micratya poeyi (Mpo) and Potimirim potimirim (Ppo); Palaemonidae: Macrobrachium faustinum adults (Mfa) and juveniles (MfaJ) and M. heterochirus adults (Mhe) and juveniles (MheJ); Xyphocarididae: Xiphocaris elongata $(\mathrm{Xel})$.

\begin{tabular}{|c|c|c|c|c|c|c|c|c|c|c|c|}
\hline \multicolumn{2}{|l|}{ Family } & \multicolumn{3}{|c|}{ Gobiidae } & \multicolumn{3}{|c|}{ Atyidae } & \multicolumn{2}{|c|}{ Palaemonidae } & \multirow{2}{*}{$\begin{array}{c}\text { Xiphocarididae } \\
\text { Xel }\end{array}$} & \multirow{2}{*}{$\begin{array}{c}\text { Functional groups } \\
\text { Herbivores / } \\
\text { Suspensivores \& } \\
\text { herbivores-benthic } \\
\text { detritus feeders / } \\
\text { Omnivores }\end{array}$} \\
\hline River & Water intake & Spl & Spu & SspJ & $\begin{array}{l}\text { Ain / } \\
\text { AinJ }\end{array}$ & Mpo & Ppo & $\begin{array}{l}\text { Mfa / } \\
\text { MfaJ }\end{array}$ & $\begin{array}{l}\text { Mhe / } \\
\text { MheJ }\end{array}$ & & \\
\hline \multirow{2}{*}{$\begin{array}{l}\text { Grand } \\
\text { Carbet }\end{array}$} & upstream & $41(7)$ & 77 (6) & $33(18)$ & $\begin{array}{c}149(6) / \\
56(6)\end{array}$ & $1852(9)$ & $0(0)$ & $\begin{array}{l}7(4) / \\
4(2)\end{array}$ & $\begin{array}{c}15(4) / \\
3(3)\end{array}$ & $5(5)$ & $\begin{array}{c}151(31) / \\
2057(24) / \\
29(13)\end{array}$ \\
\hline & downstream & $31(5)$ & $42(4)$ & $87(12)$ & $\begin{array}{c}254(7) / \\
183(6)\end{array}$ & $2124(6)$ & $0(0)$ & $\begin{array}{l}9(3) / \\
2(6)\end{array}$ & $\begin{array}{c}39(4) / \\
6(3)\end{array}$ & $25(3)$ & $\begin{array}{c}160(21) / \\
2561(19) / \\
56(18)\end{array}$ \\
\hline \multirow{2}{*}{ Pérou } & upstream & $53(2)$ & $351(5)$ & $20(6)$ & $\begin{array}{c}285(6) / \\
169(5)\end{array}$ & $543(6)$ & $8(1)$ & $\begin{array}{c}10(3) / \\
4(2)\end{array}$ & $\begin{array}{c}48(5) / \\
6(2)\end{array}$ & $4(2)$ & $\begin{array}{c}424(13) / \\
997(18) / \\
68(12)\end{array}$ \\
\hline & downstream & $121(3)$ & $151(3)$ & $33(10)$ & $\begin{array}{c}303(5) / \\
120(6)\end{array}$ & $710(6)$ & $33(3)$ & $\begin{array}{c}19(3) / \\
5(3)\end{array}$ & $\begin{array}{c}105(5) / \\
13(3)\end{array}$ & $16(3)$ & $\begin{array}{c}305(16) / \\
1133(20) / \\
142(14)\end{array}$ \\
\hline \multirow[b]{2}{*}{ Moreau } & upstream & $6(2)$ & $11(6)$ & $5(2)$ & $\begin{array}{c}26(6) / \\
7(3)\end{array}$ & $977(6)$ & $0(0)$ & $\begin{array}{l}7(3) / \\
0(0)\end{array}$ & $\begin{array}{l}6(3) / \\
0(0)\end{array}$ & $1(0)$ & $\begin{array}{c}22(10) / \\
1010(16) / \\
15(6)\end{array}$ \\
\hline & downstream & $19(4)$ & $114(6)$ & $30(6)$ & $\begin{array}{l}5(3) / \\
16(3)\end{array}$ & $590(6)$ & $0(0)$ & $\begin{array}{l}6(3) / \\
2(2)\end{array}$ & $\begin{array}{l}4(1) / \\
3(3)\end{array}$ & $0(0)$ & $\begin{array}{c}163(16) / \\
611(12) / \\
15(9)\end{array}$ \\
\hline
\end{tabular}

reference material sucrose (IAEA-C-6; $\delta^{13} \mathrm{C}=-10.8 \% \pm \pm 0.5 \%$; mean $\pm \mathrm{SD}$ ) and ammonium sulphate (IAEA-N-1; $\delta^{15} \mathrm{~N}=0.4 \%{ }_{0} \pm 0.2 \%$; mean $\pm \mathrm{SD}$ ) were used as primary analytical standards. Glycine (Merck, Darmstadt, Germany; $\delta^{13} \mathrm{C}=-47.5 \pm 0.3 \%$; $\delta^{15} \mathrm{~N}=2.25 \pm 0.3 \%$; means $\pm \mathrm{SD}$ ) was used as the secondary analytical standard. The standard deviations on multi-batch replicate measurements of secondary and internal lab standards (amphipod crustacean muscle) interspersed with samples (one replicate of each standard every 15 analyses) were $0.3 \%$ for $\delta^{13} \mathrm{C}$ and $0.2 \%$ for $\delta{ }^{15} \mathrm{~N}$.

\section{Data analysis}

Potential statistical differences among isotopic composition of basal food sources (i.e., biofilm, litter, $\mathrm{n}=6$ per station) were tested using a Kruskal-Wallis non-parametric test followed by a Dunn's Multiple Comparison Test. Data numbers for deriving matters were not sufficient to make statistical inferences $(n=2)$. Differences were considered significant at $\mathrm{p}<0.05$.

The SIBER (JACKSON et al. 2011) package (v. 2.1.3) was used in R 3.5.1 (R Development Core Team 2008) to generate bivariate standard ellipses and associated isotopic metrics. For each station, stable isotope data were explored according to two perspectives: community and functional group (i.e., trophic guild). For the community, isotopic niches were built using a data point that was the mean of all individual measurements performed in a single species' ontogenetic stage $(n=6$ per group when 
possible, Table 2). For the functional group approach, isotopic niches were built using individual measurements as input data separately for each trophic functional group that was part of the same taxonomic family: herbivores (Gobiidae), suspension feeders and herbivores/benthic detritus feeders (Atyidae) and omnivores (Palaemonidae) (Table 2). Herbivores here were primarily biofilm scrapers or browsers, as no macrophytes occurred in the river.

Standard ellipses are bivariate equivalents of the standard deviation. They contain only the 'typical' members of a population (but do not encompass outlier individuals in isotopic space). For this reason, they have been termed 'core isotopic niches', as their area (standard ellipses area, SEA) can be used as a proxy of resources most commonly used by the population (LAYMAN et al. 2012). We used SIBER's default values for SEA ( $40 \%$ of information in the ellipse). SEAs were computed using two descriptors. First, they were estimated using a frequentist approach with a correction for small sample size $\left(\mathrm{SEA}_{\mathrm{C}}\right.$, JACKSON et al. 2011). SEA ${ }_{C}$ is a robust approach when comparing small and/or unbalanced samples. Second, areas of the ellipses associated with each community or functional group were also estimated using Bayesian modelling ( $\mathrm{SEA}_{\mathrm{B}}, 2 \times 10^{4}$ iterations), and direct pairwise comparisons of $\mathrm{SEA}_{\mathrm{B}}$ were performed. Model solutions were presented using credible intervals of probability density function distributions.

The change of the standard ellipse position in the isotopic space was assessed by comparing the position of the centroids of each community or functional group in the bi-dimensional isotopic space using the hypothesis-testing framework developed by TURNER et al. (2010). Moreover, as a proxy of similarity between isotopic compositions of assemblages on each side of the water catchments, overlap between ellipses associated with the same groups upstream and downstream were computed and expressed as relative proportions of the total isotopic niche areas (i.e., cumulative SEAs for both groups).

Furthermore, only at the community scale, several niche descriptors based on convex hulls (so-called 'Layman's metrics', LAYMAN et al. 2007) were computed using SIBER 2.1.3 in R 3.5.1. They included (1) the total area of the convex hull (TA), an estimator of the total isotopic niche width that can be used as a proxy for all resources used by the population (as opposed to SEA); (2) the $\delta^{13} \mathrm{C}$ range (CR), a proxy for the diversity of basal resources (producers/organic matter pools) supporting the assemblage; (3) the $\delta^{15} \mathrm{~N}$ range (NR), typically used as an indicator of food chain length; (4) the mean distance to the centroid (CD), a proxy for the degree of separation of species' niches among the assemblage; (5) the mean nearest neighbour distance (MNND); and (6) the standard deviation of the nearest neighbour distance (SDNND), which represents the regularity of species' niches distribution in the isotopic space occupied by each community. This complementary set of metrics was used to efficiently grasp various aspects of the isotopic variability among the studied stations. For each metric, Bayesian estimates were produced. Pairwise comparisons were performed for standard ellipses and associated metrics. Pairwise comparisons were considered meaningful when the probability of difference (i.e., number of model solutions where a given solution was found) exceeded $95 \%$.

\section{Results}

The Kruskal-Wallis test indicated significant differences among isotopic compositions of basal food sources $(\mathrm{p}<0.01)$. Furthermore, the $\delta^{13} \mathrm{C}$ and $\delta^{15} \mathrm{~N}$ values of biofilm ranged from $-28.8 \%$ to $-22.9 \%$ (mean \pm s.d., $-25.4 \% \mathrm{~m} \pm 1.7 \%$ ) and from $1.6 \%$ to $7.3 \%$ (mean \pm s.d.; $4.5 \% \mathrm{o} \pm 1.5 \%$ ), respectively (Fig. 2). They did not differ significantly among rivers (Dunn's multiple comparison test, $p>0.5$ ), nor between upstream and downstream stations of each river (Dunn's multiple comparison test, $p>0.3$ ). $\delta^{13} \mathrm{C}$ and $\delta^{15} \mathrm{~N}$ values of leaf litter lying in the river ranged from $-34.4 \%$ to $-27.7 \%$ (mean \pm s.d., $-31.4 \pm 1.7 \%$ ) and from $-2.2 \%$ to $4.4 \%$ (mean \pm s.d.; $1.0 \% \pm 1.7 \%$ ), respectively (Fig. 2). $\delta^{13} \mathrm{C}$ and $\delta^{15} \mathrm{~N}$ values of leaf litter did not differ significantly among rivers (Dunn's multiple comparison test, $\mathrm{p}>0.5$ ), except the 
FROTTÉ L. et al., Trophic niches of Caribbean freshwater fauna in dammed rivers

$\delta^{15} \mathrm{~N}$ values in Moreau vs Grand Carbet (Dunn's multiple comparison test, $\mathrm{p}<0.01$ ). They did not differ between upstream and downstream stations of each river (Dunn's multiple comparison test, $\mathrm{p}>0.5$ ).

In each station, $\delta^{13} \mathrm{C}$ values of biofilm were always significantly less negative than those of litter (Dunn's Multiple Comparison Test, $\mathrm{p}<0.01$ ). In each station, $\delta^{15} \mathrm{~N}$ values of biofilm were significantly more positive than those of leaf litter (Dunn's multiple comparison test, $p<0.01$ ), except in upstream stations of the Grand Carbet and Moreau rivers, where they were similar (Dunn's multiple comparison test, $\mathrm{p}>0.1$ ). The $\delta^{13} \mathrm{C}$ and $\delta^{15} \mathrm{~N}$ values of deriving matter ranged from $-30.7 \%$ to $-25.3 \%$ (mean \pm s.d., $-28.3 \% \mathrm{~m} \pm 2.0 \%$ ) and from $-0.2 \%$ to $2.7 \%$ (mean \pm s.d.; $1.25 \% \pm 1.1 \%$ ), respectively (Fig. 2). Furthermore, the $\delta^{13} \mathrm{C}$ and $\delta^{15} \mathrm{~N}$ values of animals ranged from $-29.9 \%$ to $-11.1 \%$ (mean \pm s.d., $-21.6 \%$ $\pm 3.2 \%$ ) and from $2.9 \%$ to $8.9 \%$ (mean \pm s.d.; $5.2 \%$ $\pm 1.1 \%$ ), respectively (Fig. 3 ).

\section{Communities isotopic comparison}

The downstream communities of Pérou and Moreau water catchments occupied the same isotopic space but differed from that of Grand Carbet (Fig. 3a-c). Conversely, the upstream communities of the three rivers occupied distinct isotopic spaces.

In the Grand Carbet River, where the differences between downstream and upstream communities' isospaces were the smallest, the Euclidean distance between centroids of the two communities did not differ significantly from zero (distance $=0.83 \%, p>0.4$ ), and the standard ellipses of both communities strongly overlapped (overlap $=48.46 \%$; Fig. $3 a$ ). Conversely, in the Pérou River, centroid positions
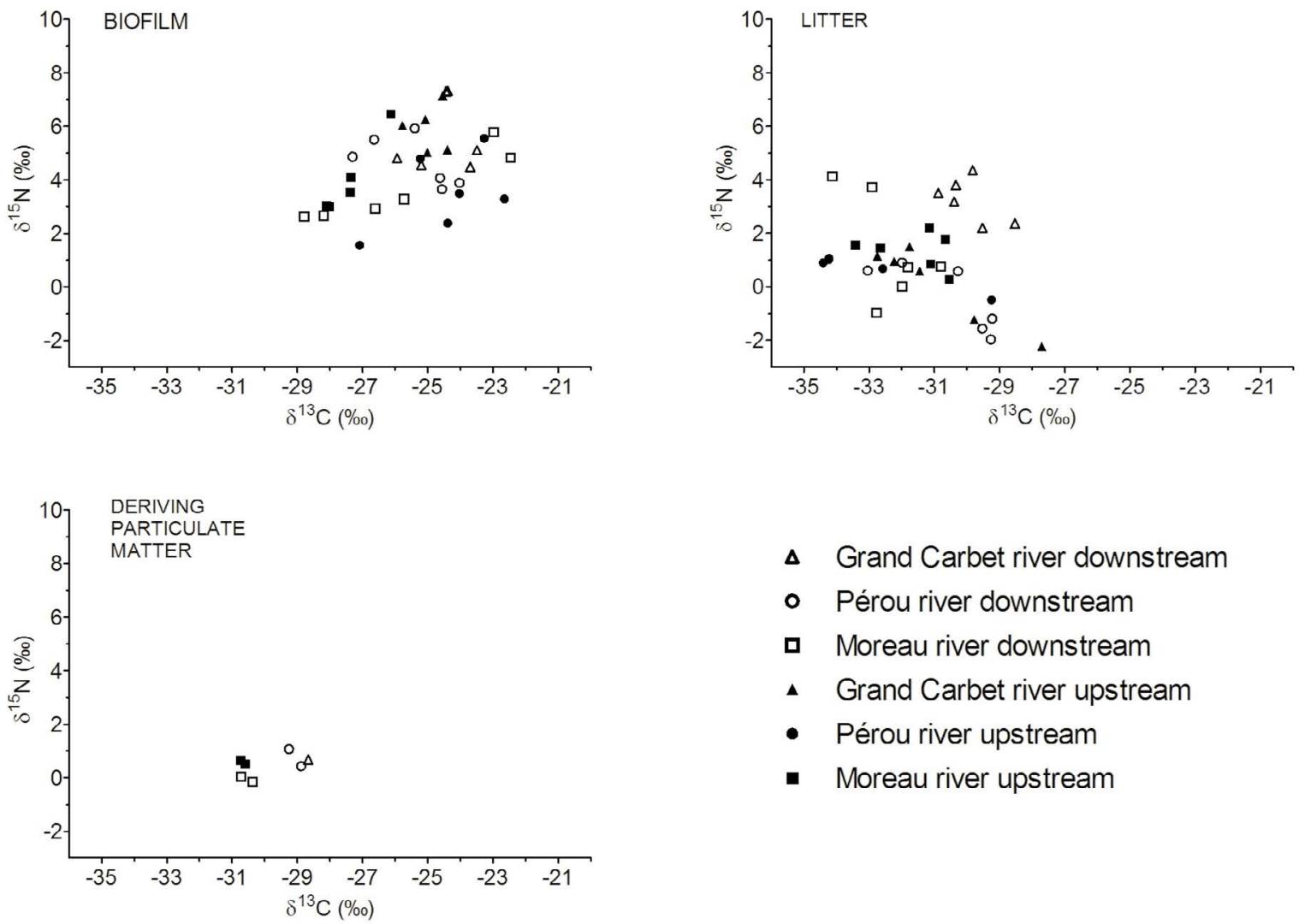

$\Delta$ Grand Carbet river downstream

- Pérou river downstream

- Moreau river downstream

- Grand Carbet river upstream

- Pérou river upstream

- Moreau river upstream

Fig. $2-\delta^{13} \mathrm{C}$ and $\delta^{15} \mathrm{~N}$ values (\%) for basal food sources sampled in three Guadeloupe rivers upstream and downstream of small dams designed for drinking water catchment. 
(a)

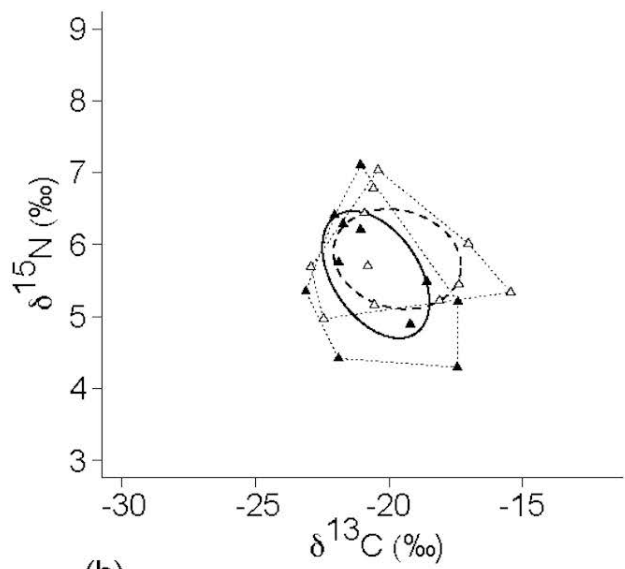

(b)

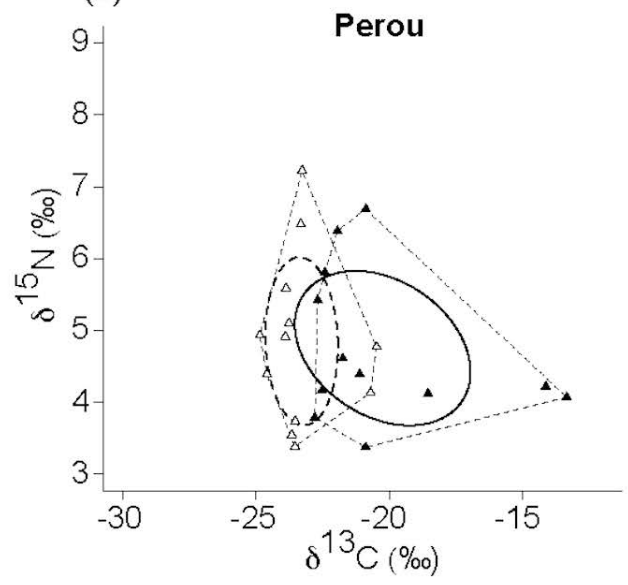

(c)

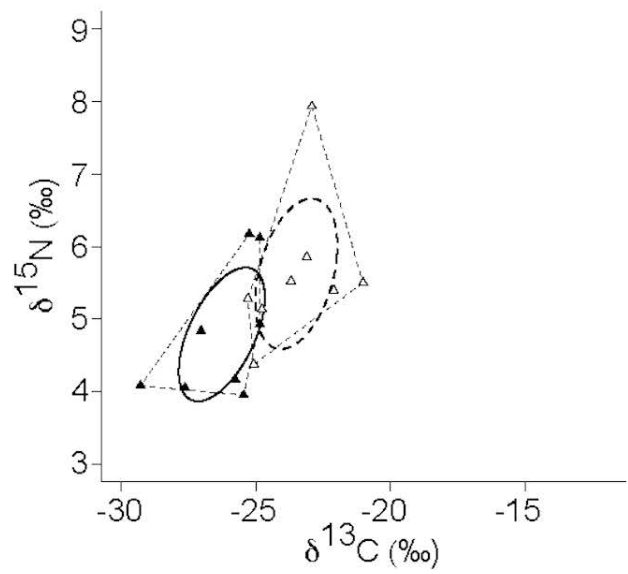

(d)

Grand Carbet

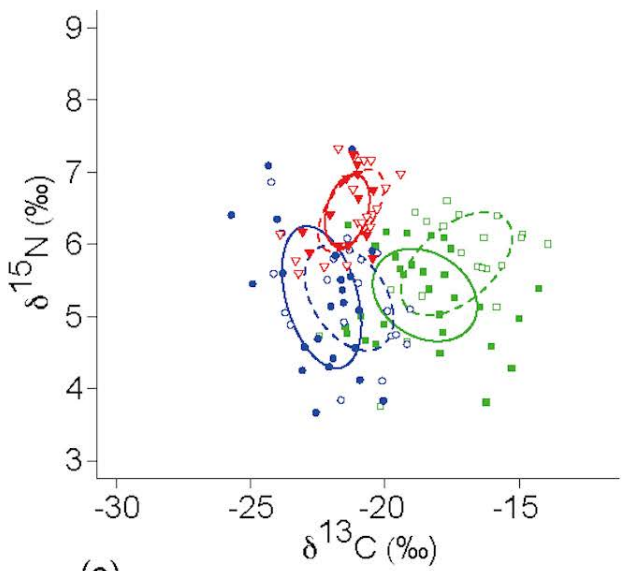

(e)

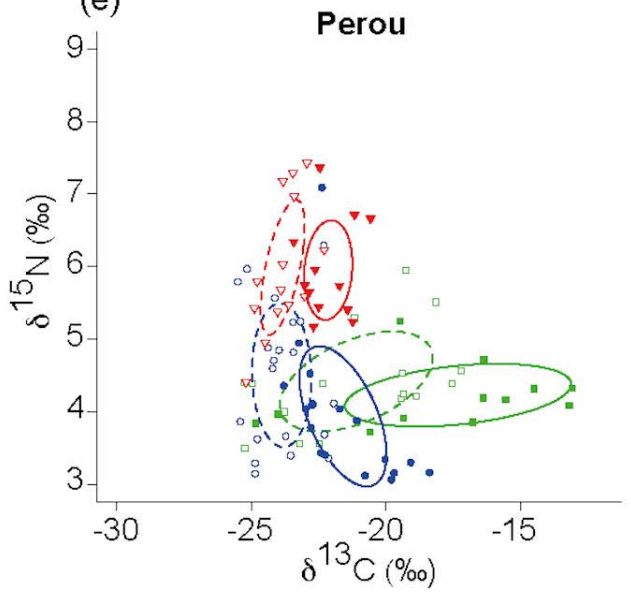

(f)

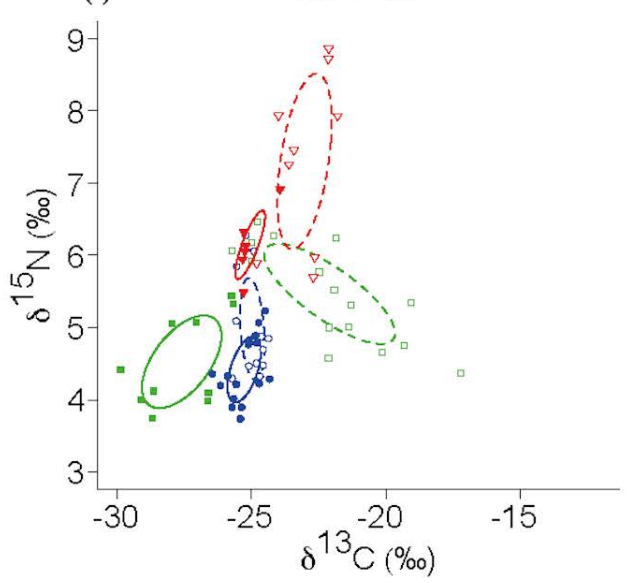

Fig. 3 - Ellipses of communities (a to c) and functional groups ( $d$ to f) from the downstream (dashed line) and the upstream (solid line) of the water catchment and group hulls of communities (grey dotted line). For a to c, each point represents the $\delta^{13} \mathrm{C}$ and $\delta^{15} \mathrm{~N}$ mean values of all individuals with the same species and the same ontogenetic stage from downstream (open symbols) and upstream (full symbols). For $\mathrm{d}$ to $\mathrm{f}$, each point shows the $\delta^{13} \mathrm{C}$ and $\delta^{15} \mathrm{~N}$ values of an individual coloured by functional group herbivores (green squares), suspensivores and herbivores/benthic detritus feeders (blue circles), omnivores (red invert triangles). 
FROTTÉ L. et al., Trophic niches of Caribbean freshwater fauna in dammed rivers

were significantly distinct (distance $=3.04 \%, p=0.001)$ with little overlap (overlap $=14.38 \%$; Fig. 3b). Likewise, in the Moreau River, downstream and upstream communities occupied different locations in bivariate isotopic space (distance $=2.89 \%, \mathrm{p}=0.001$ ) and presented almost no standard ellipse overlap (overlap $=4.20 \%$; Fig. $3 \mathrm{c}$ ).

SEAs were similar for downstream and upstream communities in the Grand Carbet and Moreau rivers, but on the Pérou River, the standard ellipse was twice as large for the upstream $\left(\mathrm{SEA}_{\mathrm{C}}=10.40 \% \mathbf{0}^{2}\right)$ than for the downstream $\left(\mathrm{SEA}_{\mathrm{C}}=4.91 \%{ }^{2}\right)$ community (probability of difference: $97 \%$ ).

In the Pérou River, several Layman's metrics were higher for upstream than downstream communities; probabilities of difference were $98 \%$ for TA, $100 \%$ for CD, 100\% for CR and 99\% for MNND (Fig. 5). Other Layman's metrics were similar between both communities. All Layman's metrics were similar between both communities in the Grand Carbet and Moreau rivers.

\section{Functional groups comparison}

Standard ellipses were similar in shape between downstream and upstream communities for the same functional group and the same river (Figs 2e-f, 3d). In the Pérou and Moreau Rivers, herbivore ellipses were rather horizontal, whereas the ellipses of the other groups were more vertical. In the Grand Carbet River, partial overlap between upstream and downstream specimens was present for all functional groups, with varying extent (30.32\% for herbivores; $37.02 \%$ for suspension feeders and herbivores/ benthic detritus feeders and $67.16 \%$ for omnivores). Ellipse centroids demonstrated a small significant change for herbivores (distance $=1.26 \%, \mathrm{p}=0.02$ ) and for suspensivores and herbivores/benthic detritus feeders (distance $=1.02 \%, \mathrm{p}=0.03$ ), but not for omnivores (distance $=0.14 \%, \mathrm{p}=0.88$ ). In the Pérou River, ellipses slightly overlapped for herbivores (overlap $=12.49 \%$ ) and for suspensivores and herbivores/benthic detritus feeders (overlap $=4.50 \%$ ) but did not overlap for omnivores. Ellipse centroids demonstrated large, significant changes between downstream and upstream for all three functional groups (herbivores: distance $=3.78 \%, \mathrm{p}=0.001$; suspensivores and herbivores/benthic detritus feeders: distance $=2.34 \%, p=0.001$; and omnivores: distance $=1.69 \%, p=0.001$ ). In the Moreau River, ellipses overlapped only for suspensivores and herbivores/benthic detritus feeders (overlap $=20.93 \%$ ). Ellipse centroids displayed a highly significant change between downstream and upstream for herbivores (distance $=5.58 \%, p=0.001)$, for omnivores $($ distance $=2.33 \%, p=0.002$ ), and for suspensivores and herbivores/benthic detritus feeders (distance $=0.63 \%, p=0.009$ ).

Model estimations suggested that SEAs (Figs $3 \mathrm{c}-\mathrm{d}, 4 \mathrm{~b}$ ) were similar for downstream and upstream functional groups in the Grand Carbet and Pérou rivers. In the Moreau River, SEAs were lower upstream $\left.\left(\mathrm{SEA}_{\mathrm{C}}=0.58 \%^{2}\right)^{2}\right)$ than downstream $\left(\mathrm{SEA}_{\mathrm{C}=} 3.86 \% \mathrm{o}^{2}\right)$ for omnivores (probability of difference: $100 \%$, Fig. 4d), but not different for herbivores and suspensivores and herbivores/benthic detritus feeders.

\section{Discussion}

According to our expectations, the isotopic composition of leaf litter lying in rivers vs the local biofilm would strongly differ in almost all localities. Nevertheless, most of the animals known to feed on biofilm were outside the isotopic mixing polygon (i.e., the polygon drawn by potential food sources' isotopic compositions, which normally encompasses all the community), with $\delta^{13} \mathrm{C}$ values generally markedly less negative than the food source on which they are expected to feed (i.e., between $-20 \%$ and $-15 \%$ vs -24 $\%$ ). The $\delta^{13} \mathrm{C}$ values of the biofilm recorded here could indicate that the sampled biofilm was partly mixed with terrestrial detritus particles or that herbivores that graze biofilm assimilate only some components of the ingested biofilm. Indeed, in these rivers, the biofilm is dominated by diatoms, but green algae and cyanobacteria are also present, being entangled in the biofilm matrix (LEFRANÇOIS et al. 2011). 
Few inter-river and no intra-river (i.e., upstream vs downstream stations) differences in isotopic compositions of basal sources (i.e., leaf litter or biofilm) were observed. This was expected for the terrestrial litter, which is globally the same between stations but not for the biofilm. Indeed, the biofilm may differ between sites due to local environmental differences affecting primary production, such as hydrological regime, nutrient supply or light availability. These parameters affect photosynthesis rates and therefore the composition of carbon stable isotopes (FINLAY et al. 1999, 2004; ISHIKAWA et al. 2012). It is possible that environmental parameters were more homogeneous than considered, leading to similar isotopic ratio values. On the other hand, the fact that the sampled biofilm was probably a mix of detrital particles and the 'true' biofilm could have masked some potential isotopic variability.

Despite the fact that no significant changes were observed in the basal resource isotopic composition, an important variability was observed in the stable isotope composition of the animal community in the six investigated stations. First, the biggest variability occurred when comparing the three rivers: animal

(a)

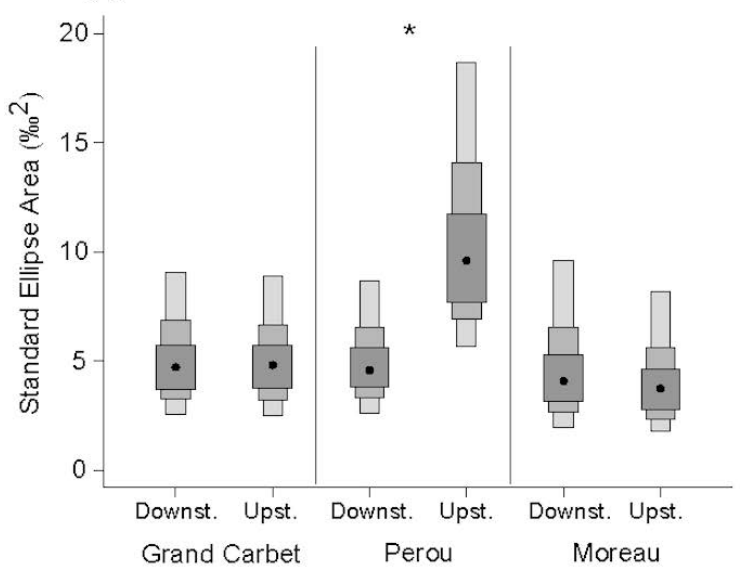

(c) Suspensivores \& herbivores/benthic

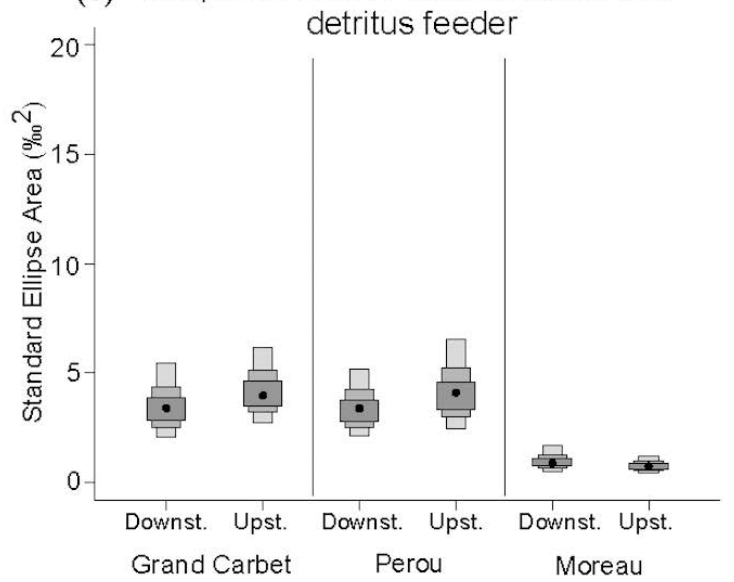

(b)

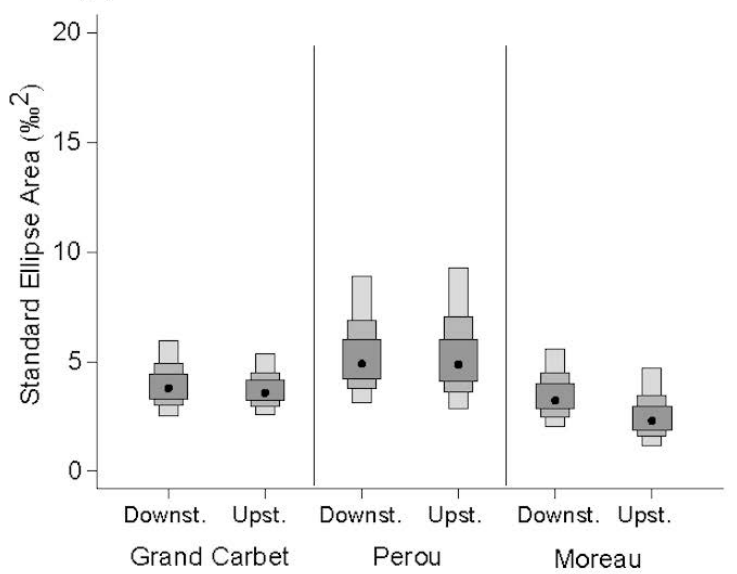

(d)

Omnivores

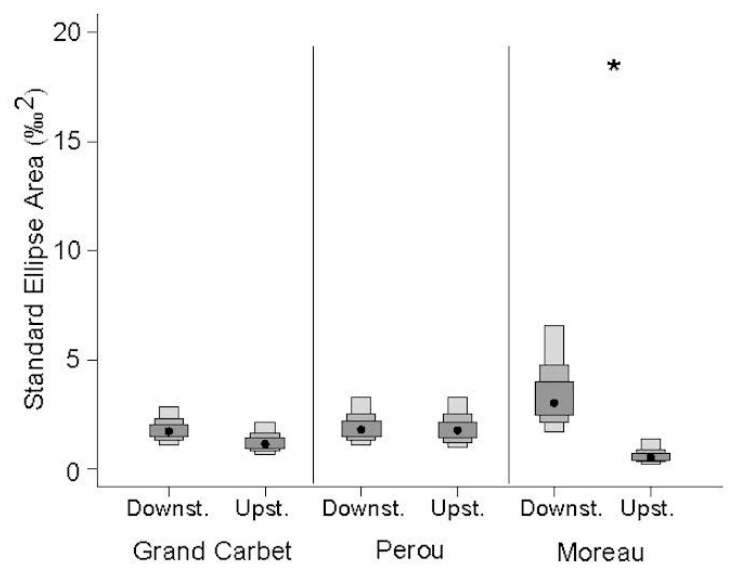

Fig. 4 - Standard ellipse areas for specific communities (a) and for each functional group (b to d) from downstream and upstream the water catchment of the three rivers. Dark, median and light-coloured boxes, and black dots are respectively the $50 \%, 75 \%$ and $95 \%$ credible intervals and modes of model solutions' probability density function distributions, respectively. The star indicates a probability of difference greater than $95 \%$. 
communities differed in the isotopic space they occupied and sometimes in their associated metrics. This observation was relatively unexpected, as this variability occurred despite common animal diversity and species composition (FROTTÉ et al. 2020a, 2020b) and similar general environmental parameters among the three rivers.

We hypothesised that the higher water availability upstream from the water catchments would lead to greater diversity of habitat and food sources, resulting in wider trophic niches of species and assemblages. In contrast to this hypothesis, variability between upstream and downstream stations of each river was only significant in the Pérou River. No clear pattern related to damming and water catchment was observed in the two other rivers, and even for the Pérou River, it was not fully established that damming was responsible for the observation. In the Pérou River, the upstream community isotopic space significantly changed towards fewer negative $\delta^{13} \mathrm{C}$ values $\left(\Delta \delta^{13} \mathrm{C}=+3.0 \%\right.$; Fig. $\left.3 \mathrm{~b}\right)$ and was twice as wide as downstream. The larger upstream isotopic space revealed that more resources were used and that a higher diversity of basal resources supported the upstream community (suggested by SEA, TA and $\mathrm{CR}$ ), but the food chain length remained the same (as suggested by $\Delta \delta^{15} \mathrm{~N}$ ). The upstream community included species with a more differentiated trophic niche in the isotopic space (as suggested by CD and MNND). This could correspond to an increase of available resources upstream (as shown by CR) and a change towards a greater contribution of the biofilm to the animal diet (i.e., as the biofilm displayed a less negative $\delta^{13} \mathrm{C}$ ). Conversely, in the Grand Carbet River, there was no significant difference between the downstream and upstream isotopic spaces at the community level: occupied isotopic spaces had similar sizes and highly overlapped. The similar Layman's metrics and the lack of change between downstream
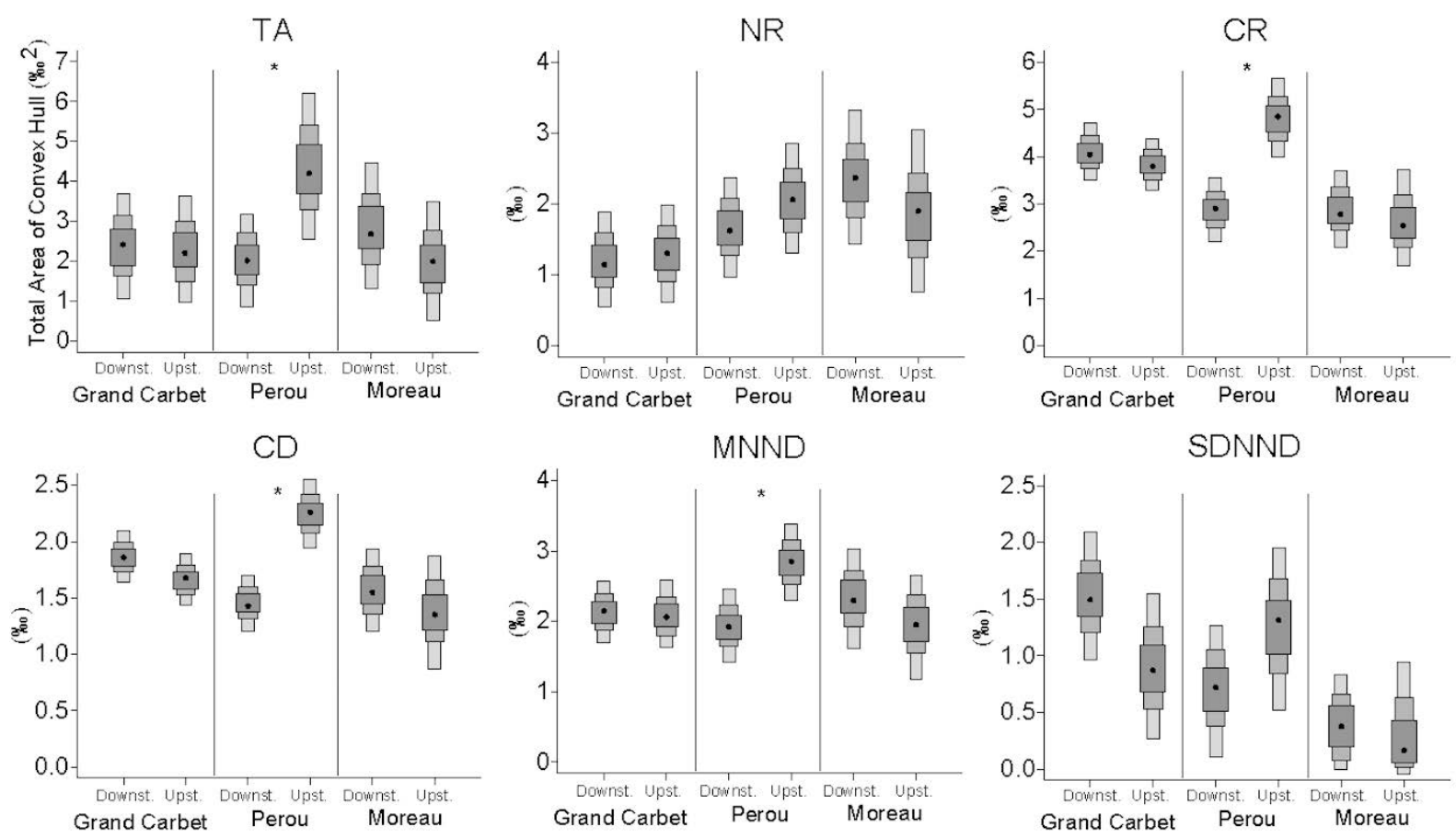

Fig. 5 - Layman's metrics for communities (individually grouped by family) from downstream and upstream the three water catchments. Dark, median and light-coloured boxes, and black dots are respectively the $50 \%, 75 \%$ and $95 \%$ credible intervals and modes of model solutions' probability density function distributions. The stars indicate a probability of difference greater than $95 \%$. TA: total area of the convex hull; NR: the $\delta^{15} \mathrm{~N}$ range; $\mathrm{CR}$ : the $\delta^{13} \mathrm{C}$ range; $\mathrm{CD}$ : the mean distance to the centroid; MNND: the mean nearest neighbour distance; SDNND: the standard deviation of the nearest neighbour distance. 
and upstream communities indicated that both communities were supported by the same producers and organic matter pools, creating a similar food chain length and the same distribution of species' trophic niche in the isotopic space. Finally, in the Moreau River, the isotopic niche width was similar between the upstream and downstream communities, but the isotopic space of the upstream community changed significantly towards more negative $\delta^{13} \mathrm{C}$ and lower $\delta^{15} \mathrm{~N}$ values $\left(\Delta \delta^{13} \mathrm{C}=-2.8 \%\right.$ and $\Delta \delta^{15} \mathrm{~N}=-0.8 \%$; Fig. 3c), which could both indicate a greater reliance on allochthonous matter.

These results indicate that small tropical rivers may be variable in their functioning at high (i.e., between river) and relatively small scales (i.e., less than $100 \mathrm{~m}$ ). It is clear that the observed variability was probably not only related to the damming itself, but also to local river characteristics. For example, the banks of the Pérou and Grand Carbet water catchments were made up of crucial vegetal cover. Conversely, the Moreau water catchment had a reduced riparian forest that increased the habitat homogenisation and decreased resource diversity. The retention of allochthonous material in Moreau could be more significant in the absence of forest on the banks.

Secondly, we also hypothesised that herbivores and omnivores feeding on the biofilm would be more affected than suspension feeders because autochthonous primary production tends to be more affected by damming than deriving terrestrial litter. Variability also appeared when exploring our data at a functional level. Nevertheless, it is mainly the topology of ellipses in the isotopic space that is affected when comparing downstream to upstream stations in each river and not necessarily associated metrics, such as ellipse areas. As for comparisons at the community scale, it was impossible to delineate a common and consistent pattern related to damming and water catchment. At the community scale, rivers generally differed more between each other than stations of the same river.

Herbivores (i.e., biofilm grazers) had distinct $\delta^{13} \mathrm{C}$ and $\delta^{15} \mathrm{~N}$ values between locations in each river (Carbet: $\Delta \delta^{13} \mathrm{C}=-1.2 \%$ and $\Delta \delta^{15} \mathrm{~N}=-0.4 \%$; Moreau: $\Delta \delta^{13} \mathrm{C}=-5.5 \%$ and $\Delta \delta^{15} \mathrm{~N}=-0.9 \%$; and Pérou: $\Delta \delta^{13} \mathrm{C}=+3.8 \%$ and $\Delta \delta^{15} \mathrm{~N}=-0.2 \%$ ). This variability could be explained by changes in the isotopic composition of the biofilm growing in different locations, differing by hydrological regime, light or nutrient availability or inorganic carbon isotopic composition (FINLAY 2004; MACKENZIE 2008; ISHIKAWA et al. 2012). However, our data did not show such isotopic composition variability of food sources between upstream and downstream stations. Therefore isotopic composition change of herbivores could also be explained by diet changes. However, the herbivorous goby $S$. punctatum studied here is known to be specialised in epilithic biofilm consumption, with a unique gardening behaviour (BARBEYRON et al. 2017) and a particular focus on diatoms (MONTI et al. 2018). It is likely that this species did not shift to other food sources (i.e., from biofilm to detritus or to a predatory diet). Therefore, we formulate the hypothesis that recorded variability is related to isotopic or composition change of the biofilm but at the scale of the goby garden, a scale not specifically investigated in our study. It is difficult to specifically rely these changes to damming more than to local river characteristics.

The suspensivore/herbivore-detritus feeder functional group had a $\delta^{15} \mathrm{~N}$ range similar to that of the herbivorous group. This group did not show a significant ellipse change in the Grand Carbet River, almost no change in the Moreau River and moderate change in the Pérou River $\left(\Delta \delta^{13} \mathrm{C}=+2.2 \%\right.$ and $\Delta \delta^{15} \mathrm{~N}=-0.6 \%$ ). Drifting particulate matter was relatively similar on both sides of the water catchment, and therefore this result was expected. Variability in Pérou could be explained by the variability of feeding habits observed in Atyidae, which filter mainly in a fast-current environment and brush mainly in a slow environment. This could indicate a preferential use of biofilm upstream of the Pérou River.

Omnivores had the highest $\delta^{15} \mathrm{~N}$ values and intermediate $\delta^{13} \mathrm{C}$ values compared to the other two groups. Their niche widths significantly decreased from downstream to upstream in the Moreau River, indicating lower diversity of resources used by the upstream community and a shorter food chain length upstream. 
FROTTÉ L. et al., Trophic niches of Caribbean freshwater fauna in dammed rivers

In the Pérou and Grand Carbet Rivers, similar niche widths on both sides of the water catchment were observed, indicating similar diversity in basal resources and food chain length. Their ellipse change was important for the omnivorous group, but once again, there was no coherence between the two rivers (Moreau: $\Delta \delta^{13} \mathrm{C}=-2.0 \%$ and $\Delta \delta^{15} \mathrm{~N}=-1.2 \%$; Pérou: $\Delta \delta^{13} \mathrm{C}=+1.7 \%$ and $\Delta \delta^{15} \mathrm{~N}=-0.0 \%$ ). In the absence of eels Anguilla rostrata (Le Sueur, 1817), whose abundance has collapsed in the West Indies over the past 30 years (BENCHETRIT \& MCCLEAVE 2016), this suggests that these species are now the top predators at these altitudes (indicated by $\delta^{15} \mathrm{~N}$ values) and integrate energy flow pathways from prey with various isotopic compositions (indicated by $\delta^{13} \mathrm{C}$ ). Shifts in omnivore ellipses between downstream and upstream of the water catchment were likely correlated to those of the other functional groups as well as to variation in animal abundance (and therefore in prey availability).

\section{Conclusion}

Our study provides evidence that food webs associated with island tropical streams may vary between rivers displaying similar features. This variability is also observable at a smaller scale but is not unambiguously related to damming or water catchment. This does not mean that damming or water extraction does not impact benthic communities. A demographic study performed in the same sites demonstrated subtle and more obvious effects (FROTTÉ et al. 2020b). Our two hypotheses (i.e., increase of upstream resources and differential response of trophic guilds) were only weakly supported, and never in an unambiguous manner. Our study showed the necessity of constraining the 'noise' of natural variability to observe and understand changes in the trophic ecology of associated fauna in relation to damming and water catchment in the rivers of these regions.

\section{Acknowledgements}

We thank Antoine Lespagnol, Anthony Perez and Soumaya El Arbaoui for their periodic assistance in field and laboratory work. G.L. is a Research Associate of the National Scientific Research Fund (F.R.S.FNRS) (Belgium). This study benefited from funding granted to Dominique Monti and provided by the French Biodiversity Agency - Réponses démographique et adaptative aux perturbations de continuité écologique chez les espèces amphidromes (Gobiidae et Palaemonidae) (2016-05/projet227).

\section{Data availability statement}

All data supporting the analyses from this paper are freely available at: http://vliz.be/en/search-datasets?module=dataset $\&$ dasid $=6696$

\section{References}

Barbeyron C., Lefrançois E., Monti D., Keith P. \& Lord C. (2017). Gardening behaviour of Sicydium punctatum (Gobioidei: Sicydiinae): in vitro experiments in the context of chlordecone pollution in Guadeloupe Island rivers. Cybium 41: 85-92. https://doi.org/10.26028/cybium/2017-412-001

Benchetrit J. \& MCCleave J.D. (2016). Current and historical distribution of the American eel Anguilla rostrata in the countries and territories of the Wider Caribbean. ICES Journal of Marine Science 73: 122-134. https://doi.org/10.1093/icesjms/fsv064

Benstead J.P., March J.G., Pringle C.M. \& Scatena F.N. (1999). Effects of a low-head dam and water catchment on migratory tropical stream biota. Ecological Applications 9: 656-668.

https://doi.org/dc6qxz 
BigGs B.J.F. \& Close M.E. (1989). Periphyton biomass dynamics in gravel bed rivers: the relative effects of flows and nutrients. Freshwater Biology 22: 209-231.

https://doi.org/10.1111/j.1365-2427.1989.tb01096.x

COAT S., Monti D., Bouchon C. \& LepoINT G. (2009). Trophic relationships in a tropical stream food web assessed by stable isotope analysis. Freshwater Biology 54: 1028-1041.

https://doi.org/10.1111/j.1365-2427.2008.02149.x

CoONEY P.B. \& KWAK T.J. (2013). Spatial extent and dynamics of dam impacts on tropical island freshwater fish assemblages. Bioscience 63: 176-190. https://doi.org/10.1525/bio.2013.63.3.6

COPLEN T.B. (2011). Guidelines and recommended terms for expression of stable-isotope-ratio and gasratio measurement results. Rapid Communications in Mass Spectrometry 25: 2538-2560.

https://doi.org/10.1002/rcm.5129

COVICH A.P., PALMER M.A. \& CROWL T.A. (1999). The role of benthic invertebrate species in freshwater ecosystems: zoobenthic species influence energy flows and nutrient cycling. Bioscience 49: 119-127. https://doi.org/10.2307/1313537

COVICH A.P., CROWL T.A. \& SCATENA F.N. (2003). Effects of extreme low flows on freshwater shrimps in a persistent tropical stream. Freshwater Biology 48: 1199-1206.

https://doi.org/10.1046/j.1365-2427.2003.01093.x

Dudgeon D. (1999). Tropical Asian Streams: Zoobenthos, Ecology and Conservation. University of Hong Kong Press, Hong Kong.

Engman A.C., KWAK T.J. \& CoPe W.G. (2018). Do postlarval amphidromous fishes transport marinederived nutrients and pollutants to Caribbean streams? Ecology Freshwater Fish 27: 847-856.

https://doi.org/10.1111/eff.12397

FIÈVET E., DOLEDEC S. \& LiM. P. (2001a). Distribution of migratory fishes and shrimps along multivariate gradients in tropical island streams. Journal of Fish Biology 59: 390-402. https://doi.org/10.1006/jfbi.2001.1648

Fièvet E., Tito DE Morais L., Tito DE Morais A., Monti D. \& TACheT H. (2001b). Impacts of an irrigation and hydroelectric scheme in a stream with a high rate of diadromy (Guadeloupe, Lesser Antilles): can downstream alterations affect upstream faunal assemblages? Archiv für Hydrobiologie 151 (3): 405-425. https://doi.org/10.1127/archiv-hydrobiol/151/2001/405

FINLAY J.C. (2004). Patterns and controls of lotic algal stable carbon isotope ratios. Limnology and Oceanography 49: 850-861. https://doi.org/10.4319/1o.2004.49.3.0850

FINLAY J.C., POWER M.E. \& CABANA G. (1999). Effects of water velocity on algal carbon isotope ratios: implications for river food web studies. Limnology and Oceanography 44: 1198-1203.

https://doi.org/10.4319/1o.1999.44.5.1198

Freeman M.C., Pringle C.M., Greathouse E.A. \& Freeman B.J. (2003). Ecosystem-level consequences of migratory faunal depletion caused by dams. American Fisheries Society Symposium 35: $255-266$.

Frotté L., Cordonnier S., Bezault E. \& Monti D. (2020a). Effects of dams on demographic structures of amphidromous fish and crustacean species in Caribbean rivers. Cybium 44 (2): 113-125. https://doi.org/10.26028/cybium/2020-442-003

Frotté L., Ringelstein J., Monti D., Robert M., Pécheyran C., Améziane N. \& Tabouret H. (2020b). Detection of full and limited amphidromous migratory dynamics of fish in Caribbean rivers. Ecology of Freshwater Fish 29: 132-144. https://doi.org/10.1111/eff.12501 
FROTTÉ L. et al., Trophic niches of Caribbean freshwater fauna in dammed rivers

Greathouse E.A., Pringle C.M. \& Holmquist J.G. (2006). Conservation and management of migratory fauna: dams in tropical streams of Puerto Rico. Aquatic Conservation: Marine and Freshwater Ecosystems 16: 695-712. https://doi.org/10.1002/aqc.804

ISHIKAWA N.F., DOI H. \& FINLAY J.C. (2012). Global meta-analysis for controlling factors on carbon stable isotope ratios of lotic periphyton. Oecologia 170: 541-549.

https://doi.org/10.1007/s00442-012-2308-x

JACKSON A.L., INGER R., PARNELl A.C. \& BEARHOP S. (2011). Comparing isotopic niche widths among and within communities: SIBER - stable isotope Bayesian ellipses in R. Journal of Animal Ecology 80: 595-602. https://doi.org/10.1111/j.1365-2656.2011.01806.x

JENKINS A.P., JUPITER S.D., QAUQUA I. \& ATHERTON J. (2010). The importance of ecosystem-based management for conserving aquatic migratory pathways on tropical high islands: a case study from Fiji. Aquatic Conservation: Marine and Freshwater Ecosystems 20: 224-238.

https://doi.org/10.1002/aqc.1086

KEITH P. (2003). Biology and ecology of amphidromous Gobiidae of the Indo-Pacific and the Caribbean regions. Journal of Fish Biology 63: 831-847. https://doi.org/10.1046/j.1095-8649.2003.00197.x

KiKKeRT D.A., CROWL T.A. \& COVICH A.P. (2009). Upstream migration of amphidromous shrimps in the Luquillo Experimental Forest, Puerto Rico: temporal patterns and environmental cues. Journal of the North American Benthological Society 28: 233-246. https://doi.org/10.1899/08-019.1

Kupilas B., Friberg N., McKie B.G., Jochmann M.A., Lorenz A.W. \& Hering D. (2016). River restoration and the trophic structure of benthic invertebrate communities across 16 European restoration projects. Hydrobiologia 769: 105-120. https://doi.org/10.1007/s10750-015-2569-6

LAMARQUE P. (1990). Electrophysiology of fish in electric fields. In: COWX I.G. (ed.) Developments in Electric Fishing: 4-33. Fishing News Books, Oxford.

LAU D.C.P., LeUnG K.M.Y. \& DUdGeON D. (2009). Are autochthonous foods more important than allochthonous resources to benthic consumers in tropical headwater streams? Journal of the North American Benthological Society 28: 426-439. https://doi.org/10.1899/07-079.1

LAYMan C.A., ArRington D.A., Montaña C.G. \& Post D.M. (2007a). Can stable isotope ratios provide for community-wide measures of trophic structure? Ecology 88: 42-48. https://doi.org/10.1890/08-0167.1

layman C.A., Araujo M.S., Boucek R., Hammerschlag-Peyer C.M., Harrison E., Jud Z.R., Matich P., Rosenblatt A.E., Vaudo J.J., Yeager L.A., Post D.M. \& Bearhop S. (2012). Applying stable isotopes to examine food-web structure: an overview of analytical tools. Biological Reviews 87 (3): 545-562. https://doi.org/10.1111/j.1469-185X.2011.00208.x

Lefrançois E., CoAT S., Lepoint G., VAchiéry N., Gros O. \& Monti D. (2011). Epilithic biofilm as a key factor for small-scale river fisheries on Caribbean islands. Fisheries Management and Ecology 18 (3): 211-220. https://doi.org/10.1111/j.1365-2400.2010.00767.x

MACKENZIE R.A. 2008. Impacts of riparian forest removal on Palauan streams. Biotropica 40: 666-675. https://doi.org/10.1111/j.1744-7429.2008.00433.x

March J.G., Benstead J.P., Pringle C.M. \& SCATEna F.N. (2003). Damming tropical island streams: problems, solutions, and alternatives. Bioscience 53: 1069-1078. https://doi.org/bp9nnb

MCDowall R.M. (1997). The evolution of diadromy in fishes (revisited) and its place in phylogenetic analysis. Reviews in Fish Biology and Fisheries 7: 443-462. https://doi.org/10.1023/A:1018404331601 
Monti D., Keith P. \& VigneuX É. (2010). Atlas des poissons et des crustacés d'eau douce de la Guadeloupe. Muséum national d'histoire naturelle, Paris, 128 p.

Monti D., Lefrançois E., Lord C., Mortillaro J.-M., LoPez P.J. \& KeITH P. (2018). Selectivity on epilithic diatom consumption for two tropical sympatric gobies: Sicydium punctatum Perugia, 1986 and Sicydium plumieri (Bloch, 1786). Cybium 3: 1-9. https://doi.org/10.26028/cybium/2018-424-007

MYERS G.S. (1949). Usage of anadromous, catadromous and allien terms for migratory fishes. Copeia 2: 89-97. https://doi.org/10.2307/1438482

Ovidio M. \& PHILIPPART J.-C. (2002). The impact of small physical obstacles on upstream movements of six species of fish: synthesis of a 5-year telemetry study in the River Meuse basin. Hydrobiologia 483: 55-69. https://doi.org/10.1007/978-94-017-0771-8_8

PRINGLE C.M. (1997). Exploring how disturbance is transmitted upstream: going against the flow. Journal of the North American Benthological Society 16: 425-438. https://doi.org/10.2307/1468028

PRINGLE C.M. \& BLAKE G.A. (1994). Quantitative effects of atyid shrimp (Decapoda: Atyidae) on the depositional environment in a tropical stream: use of electricity for experimental exclusion. Canadian Journal of Fisheries and Aquatic Sciences 51: 1443-1450. https://doi.org/10.1139/f94-144

SANDRE \& EAU FRANCE (2019). Obstacles à l'écoulement - Guadeloupe. Available from: http://www.sandre.eaufrance.fr/atlas/srv/fre/catalog.search\#/map

SMITH G.C., COVICH A.P. \& BRASHER A.M.D. (2003). An ecological perspective on the biodiversity of tropical island streams. Bioscience 53: 1048-1051. https://doi.org/d2wmp2

Tabouret H., Lord C., Bareille G., Pécheyran C., Monti D. \& Keith P. (2011). Otolith microchemistry in Sicydium punctatum: indices of environmental condition changes after recruitment. Aquatic Living Resourses 24: 369-378. https://doi.org/10.1051/alr/2011137

TURner T.F., COLLYER M.L. \& KRABBENHOFT T.J. (2010). A general hypothesis-testing framework for stable isotope ratios in ecological studies. Ecology 91: 2227-2233. https://doi.org/10.1890/09-1454.1

WALKER M.K., YANKE E.A. \& GINGERICH W.H. (1994). Use of electronarcosis to immobilize juvenile and adult northern pike. The Progressive Fish-Culturist 56: 237-243. https://doi.org/crm4b4

Watanabe S., Iida M., Lord C., Keith P. \& Tsukamoto K. (2013). Tropical and temperate freshwater amphidromy: a comparison between life history characteristics of Sicydiinae, ayu, sculpins and galaxiids. Reviews in Fish Biology and Fisheries 24: 1-14. https://doi.org/10.1007/s11160-013-9316-8

XU J., ZHANG M. \& XIE P. (2008). Stable isotope changes in freshwater shrimps (Exopalaemon modestus and Macrobrachium nipponensis): trophic pattern implications. Hydrobiologia 605: 45-54.

https://doi.org/10.1007/s10750-008-9299-y

Received: 27 March 2020

Accepted: 20 May 2021

Published on: 9 June 2021

Branch editor: Merlijn Jocqué 